\title{
Reaksi Pasar Atas Kesepakatan Investasi Bidang Infrastruktur dalam Pertemuan International Monetary Fund-World Bank 2018
}

\author{
P. Sigit Wahyudhi ${ }^{1}$ \\ I G.N. Agung Suaryana ${ }^{2}$ \\ ${ }^{1,2}$ Fakultas Ekonomi dan Bisnis Universitas Udayana (Unud), Bali, Indonesia \\ e-mail: sigitwahyudhi1996@gmail.com
}

\begin{abstract}
ABSTRAK
Penelitian ini bertujuan menguji reaksi pasar modal atas pengumuman kesepakatan investasi bidang infrastruktur dalam pertemuan tahunan International Monetary Fund (IMF) - World Bank 2018. Pengukuran reaksi pasar pada penelitian ini menggunakan Cumulative Abnormal Return (CAR). Sampel yang digunakan adalah perusahaan yang tergolong Indeks LQ-45 di Bursa Efek Indonesia (BEI) dengan periode pengamatan selama 7 hari. Metode sampling menggunakan teknik purposive sampling. Teknik analisis data yang digunakan adalah one sample t-test. Hasil analisis data menunukkan terdapat reaksi negatif pasar modal atas pengumuman kesepakatan investasi bidang infrastruktur dalam pertemuan tahunan IMF-World Bank 2018. Penelitian ini dapat dijadikan pertimbangan bagi investor untuk berinvestasi terkait adanya peristiwa-peristiwa eksternal perusahaan.

Kata Kunci: Reaksi Pasar, Event Study, Abnormal Return, Peristiwa Eksternal Perusahaan.
\end{abstract}

\begin{abstract}
This study aims to examine the capital market reaction to the announcement of infrastructure investment agreements at the International Monetary Fund (IMF) - World Bank annual meeting 2018. Measurement of market reactions in this study uses Cumulative Abnormal Return (CAR). The sample used in this study are companies which engaged in LQ-45 Index on the Indonesia Stock Exchange (IDX) with 7 days observation period. The sampling method used is purposive sampling technique. The data analysis technique used is one sample t-test. Based on the results of the analysis it was found that there is a negative reaction to the announcement of an investment agreement on infrastructure in the 2018 IMF-World Bank annual meeting 2018. This research could be used as a consideration for investors to invest according to company's external events.

Keywords: Market Reaction, Event Study, Abnormal Return, Company External Events.
\end{abstract}

\section{PENDAHULUAN}

Pasar modal memegang peranan yang penting dalam perekonomian suatu negara.

Semakin berkembang pasar modal di suatu negara akan mempercepat pertumbuhan ekonomi di negara tersebut. Selain menjadi indikator perkembangan ekonomi suatu negara pasar modal juga dapat dijadikan alternatif tempat untuk berinvestasi (Aryasa, 2017). Dalam mengambil keputusan investasi, para investor 
tentunya didasari oleh pertimbangan yang rasional yaitu dengan mempertimbangkan risiko dan tingkat keuntungan yang diharapkan (expected return). Oleh karena itu, maka para investor tentunya harus memiliki informasi baik dari perusahaan langsung maupun informasi dari luar perusahaan yang mampu menggambarkan risiko dan tingkat keuntungan yang diharapkan dari investasi yang dilakukan.

Informasi sendiri dibagi menjadi dua yaitu informasi internal dan informasi eksternal (Fama, 1997). Informasi internal merupakan informasi atas peristiwa yang terjadi di dalam perusahaan misalnya kebijakan dividen. Informasi eksternal merupakan informasi atas peristiwa yang terjadi diluar kebijakan yang dibuat oleh perusahaan, misalnya peristiwa lainnya yang dapat berpengaruh terhadap tingkat kestabilan kondisi perekonomian pada suatu negara. Kandungan informasi memiliki kaitan yang erat dengan konsep pasar efisien, yaitu pasar yang bereaksi cepat dan akurat untuk mencapai harga keseimbangan baru yang mencerminkan informasi yang tersedia (Hartono, 2015:517).

Tandelilin (2010:223) mengklasifikasikan bentuk pasar efisien secara informasional ke dalam tiga kategori, yaitu efisiensi pasar bentuk lemah (weak form), efisiensi pasar bentuk setengah kuat (semi-strong form), dan efisiensi pasar bentuk kuat (strong form). Bentuk setengah kuat merupakan bentuk pasar efisien yang harga sahamnya mencerminkan semua informasi yang dipublikasikan secara relevan. Artinya, harga pasar saham yang dapat dibentuk sekarang ini telah berisikan informasi masa lalu ditambahkan dengan informasi publik. Pasar akan 
memberikan reaksi pasar positif untuk berita baik dan reaksi negatif untuk berita buruk adalah prediksi dari hipotesis pasar efisien (Aryasa, 2017).

Pengujian kandungan informasi dapat digunakan untuk melihat ada atau tidaknya reaksi pasar modal atas suatu peristiwa. Pasar modal akan bereaksi apabila suatu peristiwa mengandung informasi yang ditunjukkan dengan adanya abnormal return. Salah satu peristiwa yang dapat dijadikan informasi eksternal yang diyakini dapat mempengaruhi pergerakan harga saham di pasar modal saat ini adalah adanya Kesepakatan Investasi Bidang Infrastruktur dalam Pertemuan Tahunan International Monetary Fund (IMF)-World Bank 2018 yang diumumkan pada tanggal 8 Oktober 2018 untuk kemudian ditandatangani pada tanggal 11 Oktober 2018 di Nusa Dua, Bali. Pertemuan ini membahas beberapa hal, yaitu pengurangan kemiskinan, pembangunan ekonomi internasional, dan isu-isu global lainnya.

Selain bertujuan menghasilkan kebijakan-kebijakan strategis di bidang perekonomian, pertemuan ini juga menjadi ajang bagi Indonesia untuk menunjukkan kekuatan dan stabilitas ekonominya di hadapan dunia internasional. Kekuatan dan stabilitas perekonomian Indonesia pun diakui oleh Direktur Pelaksana IMF yaitu Christine Lagarde yang menilai Indonesia merupakan negara dengan fundamental perekonomian yang kuat dan serta pertumbuhan ekonomi yang stabil sehingga tidak tertular krisis ekonomi yang lebih luas. Menurutnya sejumlah kebiakan fiskal dan moneter yang diambil pemerintah Indonesia membuat rapor perekonomian Indonesia terbilang bagus. (https://www.msn.com, diakses tanggal 19 Oktober 2018). 
Penandatangan kesepakatan investasi bidang infrastruktur yang dilaksanakan pada tanggal 11 Oktober 2018 di Nusa Dua, Bali merupakan salah satu agenda dalam Pertemuan Tahunan IMF-World Bank 2018. Melalui kesepakatan ini, pemerintah Indonesia berhasil meraup dana investasi sebesar 202 Triliun rupiah di bidang infrastruktur melalui beberapa perusahaan BUMN. Penandatanganan investasi ini diyakini oleh beberapa pengamat akan menciptakan sentimen positif bagi investor karena nilai investasi yang besar tersebut menunjukkan bahwa Indonesia merupakan tempat berinvestasi yang tepat dan aman serta memiliki potensi pertumbuhan ekonomi yang menanikan. Hal ini juga didukung oleh pernyataan beberapa tokoh penting dunia di bidang ekonomi yang memuji fundamental dan pertumbuhan ekonomi Indonesia yang stabil.

Dalam investasi yang ditandatangani oleh perusahaan BUMN terkait pengembangan infrastruktur ini juga melibatkan peran pasar modal didalamnya. Pada konfrensi pers penandatanganan investasi tersebut, menteri BUMN Rini Soemarmo menyampaikan bahwa berdasarkan jenis investasi, 80 persen nilai transaksi berasal dari kerja sama strategis perusahaan BUMN serta perusahaan swasta yang terdaftar di BEI dengan investor. Sementara 20 persen sisanya merupakan investasi melalui pasar modal dan pembiayaan proyek. Menteri BUMN ini berharap para investor mengetahui adanya komitmen pemerintah yang tinggi untuk mendorong peran pihak swasta dalam untuk turut serta dalam pembangunan infrastruktur dan inovasi instrumen keuangan melalui bank BUMN yang terdaftar di BEI untuk pembiayaan infrastruktur. Oleh karena itu, peranan 
pasar modal dalam pendanaan proyek infrastruktur diyakini akan menarik minat investor pasar modal.

Investasi bidang infrastruktur ini tentunya bertujuan untuk mengembangkan infrastruktur di Indonesia yang bermanfaat dalam mendorong pertumbuhan ekonomi antar daerah karena mobilisasi barang dan jasa antar daerah semakin mudah, sehingga akan menciptakan pertumbuhan ekonomi Indonesia yang lebih baik lagi. Penelitian Juita (2013) menemukan pertumbuhan ekonomi berpengaruh signifikan dan arahnya positif terhadap pasar modal Indonesia yang bisa dilihat dari Indeks Harga Saham Gabungan (IHSG). Selain itu, dengan terciptanya pertumbuhan ekonomi tersebut maka akan meningkatkan sentimen positif terhadap pasar modal Indonesia sehingga mampu menarik minat investor khususnya investor asing untuk berinvestasi.

Terdapat beberapa penelitian sebelumnya yang meneliti reaksi pasar terhadap informasi eksternal baik itu berupa regulasi baru yang dikeluarkan oleh pemerintah, maupun peristiwa lainnya yang dapat berpengaruh terhadap tingkat kestabilan kondisi perekonomian pada suatu negara. Prameswari (2017) meneliti mengenai reaksi pasar atas Pilkada DKI Jakarta 2017 dan tidak ditemukan perbedaan rata-rata abnormal return sebelum dan sesudah peristiwa Pilkada DKI Jakarta 2017. Nanda (2017) meneliti mengenai reaksi pasar modal Indonesia terhadap kebijakan Tax Amnesty Indonesia pada saham LQ45 tahun 2016 -2017 mendapatkan hasil penelitian bahwa tidak terdapat perbedaan rata-rata abnormal return sebelum dan sesudah penerapan kebijakan Tax Amnesty di Indonesia. Suparsa dan Ratnadi (2014) dalam penelitiannya tidak menemukan perbedaan 
abnormal return atas pengumuman kenaikan harga BBM pada saham yang tergolong LQ 45.

Sementara itu, Purba dan Handayani (2017) menyatakan bahwa terdapat abnormal return pada peristiwa politik pilkada DKI Jakarta 2017 putaran kedua. Hasil penelitian tersebut juga sejalan dengan penelitian Putra (2018) yang mendapatkan hasil bahwa terdapat reaksi pasar modal atas pengumuman kemenangan Donald Trump menjadi presiden Amerika Serikat. Sopyana (2016) menemukan hasil bahwa terdapat terdapat perbedaan reaksi pasar pada peristiwa pengumuman pemenang Pemilu Presiden 2014. Xiao \& Gao et al. (2017) meneliti tentang dampak perubahan peraturan pada industri makanan kasus hukum keamanan pangan China menghasilkan cumulative abnormal return yang signifikan.

Penelitian dilakukan untuk menguji reaksi pasar atas Kesepakatan Investasi Bidang Infrastruktur dalam Pertemuan Tahunan IMF-World Bank 2018. Sehingga, mampu menyumbangkan bukti empiris mengenai teori kandungan informasi dan efisiensi pasar. Manfaat lain dari penelitian ini khususnya untuk para investor adalah investor diharapkan dapat menjadikan penelitian ini sebagai acuan dalam mengambil keputusan berinvestasi jika terdapat suatu peristiwa yang terjadi khususnya berkaitan dengan peristiwa pengumuman kesepakatan di bidang ekonomi.

Watts dan Zimmerman et al. (1986) menyatakan bahwa kandungan informasi digunakan untuk isu-isu yang menguji apakah suatu event seperti mempunyai pengaruh terhadap harga saham pada waktu event terjadi. Kandungan 
informasi merupakan release berita baru atau pengumuman menyebabkan revisi dalam distribusi return sekuritas (Foster, 1986). Foster (1986) menyatakan bahwa terdapat tiga faktor yang mempengaruhi kandungan informasi suatu pengumuman, yaitu: Ekspektasi pasar modal terhadap kandungan dan waktu suatu pengumuman; Implikasi suatu pengumuman terhadap distribusi return sekuritas di waktu yang akan dating; dan Event study dapat digunakan untuk menguji kandungan informasi (information content) dari suatu pengumuman dan dapat juga digunakan untuk menguji efisiensi pasar bentuk setengah kuat.

Teori efisiensi pasar menjelaskan tentang respon pasar terhadap suatu informasi yang masuk dan bagaimana selanjutnya informasi tersebut mempengaruhi harga-harga sekuritas menuju harga keseimbangan yang baru. Tandelilin (2010:218) menyatakan bahwa efisiensi dalam konteks investasi diistilahkan sebagai "no one can beat the market" yang diartikan "tidak seorang pun bisa mengambil untung dari pasar". Jadi, jika pasar efisien dan semua informasi bisa diakses secara mudah dan dengan biaya yang murah oleh semua pihak di pasar, maka harga yang terbentuk adalah harga keseimbangan, sehingga tidak seorang pun yang memperoleh keuntungan tak normal dengan memanfaatkan informasi yang dimilikinya. Pasar modal efisien diartikan sebagai pasar dimana harga saham sudah menunjukkan informasi secara cepat dan ada kaitan (relevan) (Husnan, 2001:264).

Hartono (2015:585) menjelaskan bahwa studi peristiwa (event study) merupakan studi yang digunakan untuk menguji dampak berbagai peristiwa pada efisiensi pasar saham yang mempelajari reaksi pasar terhadap suatu 
peristiwa (event) yang informasinya dipublikasikan sebagai suatu pengumuman. Studi peristiwa bermanfaat dalam menganalisis reaksi pasar terhadap harga suatu sekuritas. Reaksi pasar ditunjukan dengan adanya perubahan harga dari sekuritas yang bersangkutan. Reaksi ini dapat diukur dengan menggunakan return sebagai nilai perubahan harga atau dengan menggunakan abnormal return (Pratama dan Sudhiarta, 2014).

Pertemuan Tahunan IMF-World Bank 2018 adalah pertemuan tahunan yang diselenggarakan oleh Dewan Gubernur IMF dan World Bank. Penandatangan kesepakatan investasi bidang infrastruktur yang dilaksanakan pada tanggal 11 Oktober 2018 di Nusa Dua, Bali merupakan salah satu agenda dalam Pertemuan Tahunan IMF-World Bank 2018. Dalam investasi yang ditandatangani ini juga melibatkan peran pasar modal didalamnya. Menteri BUMN ini mengharapkan para investor bisa mengetahui tingginya komitmen pemerintah dalam mendorong keterlibatan pihak swasta untuk turut serta dalam hal pembangunan infrastruktur secara langsung maupun dengan menciptakan inovasi instrumen keuangan untuk membiayai proyek infrastruktur di Indonesia. Oleh karena itu, adanya peranan pasar modal dalam pendanaan proyek infrastruktur ini diyakini akan menarik minat investor di pasar modal. Berdasarkan teori, riset dan logika yang dikembangkan maka hipotesis dalam penelitian dirumuskan sebagai berikut:

$\mathrm{H}_{1}$ : Terdapat reaksi pasar atas pengumuman kesepakatan investasi bidang infrastruktur dalam pertemuan tahunan IMF-World Bank 2018. 


\section{METODE PENELITIAN}

Penelitian menggunakan metode short event window selama 7 hari yang terdiri dari 3 hari sebelum Kesepakatan Investasi Bidang Infrastruktur dalam Pertemuan Tahunan IMF-World Bank 2018 dilaksanakan (t-3), 1 hari saat pelaksanaan Pertemuan Tahunan IMF-World Bank 2018 (t0), dan 3 hari sesudah Kesepakatan Investasi Bidang Infrastruktur dalam Pertemuan Tahunan IMF-World Bank 2018 dilaksanakan (t+3). Hal tersebut didukung oleh Penelitian Widi dan Surya (2015), Sudewa P dan Maria M. (2015), dan Sari (2017). Peneliti menilai dengan menggunakan 7 hari merupakan jumlah yang tepat untuk mengetahui respon dari para investor atas kejadian pengumuman suatu peristiwa.

Tanggal peristiwa (event date) pada penelitian ini adalah pada tanggal 8 Oktober 2018. Berdasarkan pemberitaan di media masa, informasi mengenai kesepakatan investasi bidang infrastruktur dalam pertemuan IMF-World Bank 2018 ini pertama kali dipublikasikan pada tanggal 8 Oktober 2018. Oleh karena itu, penelitian ini menetapkan tanggal peristiwa pada tanggal 8 Oktober 2018 meskipun kesepakatan ini baru ditandatangani secara seremonial pada tanggal 11 Oktober 2018. Penelitian berlokasi di Bursa Efek Indonesia, obyek penelitian ini yaitu abnormal return di sekitar tanggal pengumuman kesepakatan investasi bidang infrastruktur dalam (IMF)-World Bank 2018. Variabel terikat dalam penelitian ini adalah abnormal return dan variabel bebasnya adalah Kesepakatan Investasi Bidang Infrastruktur dalam Pertemuan Tahunan IMF-World Bank 2018.

Hartono (2015:647) menjelaskan bahwa abnormal return adalah kelebihan dari return yang sesungguhnya terjadi terhadap return ekspektasian (return yang 
diharapkan oleh investor), maka return tak normal (abnormal return) adalah selisih antara return sesungguhnya yang terjadi dengan return ekspektasian.

Langkah-langkah untuk mencari abnormal return, yaitu diawali dengan menghitung return sesungguhnya atau return realisasian. Return realisasian atau return sesungguhnya merupakan return yang terjadi pada waktu ke-t yang merupakan selisih dari harga sekarang relatif terhadap harga sebelumnya atau dapat dihitung dengan rumus (Hartono, 2015:648):

$$
R_{i, t}=\frac{P_{i, t}-P_{i, t-1}}{P_{i, t}-1}
$$

Keterangan:

$\mathrm{R}_{\mathrm{i}, \mathrm{t}} \quad=$ return saham i pada periode ke-t

$\mathrm{P}_{\mathrm{i}, \mathrm{t}} \quad=$ harga saham penutupan perusahaan i pada periode ke-t

$\mathrm{P}_{\mathrm{i}, \mathrm{t}-1}=$ harga saham penutupan perusahaan i pada periode ke-t-1

Langkah selanjutnya adalah menghitung return ekspektasian (expected return). Return ekspektasian merupakan return yang harus diestimasi (Hartono, 2015:648). Mengestimasi return ekspektasian dalam penelitian ini menggunakan model market-adjusted model karena model ini beranggapan bahwa penduga yang terbaik untuk mengestimasi return suatu sekuritas adalah return indeks pasar (Hartono, 2015:659). Dirumuskan sebagai berikut:

$$
\mathrm{E}\left[\mathrm{R}_{\mathrm{i}, \mathrm{t}}\right]=\mathrm{R}_{\mathrm{mnt}}
$$

Keterangan:

$\mathrm{E}\left[\mathrm{R}_{\mathrm{i}, \mathrm{t}} \mathrm{t}=\right.$ return ekspektasian sekuritas ke-i pada periode peristiwa ke-t $\mathrm{R}_{\mathrm{mt}} \quad=$ return pasar pada periode $\mathrm{t}$ 
Perhitungan return pasar dalam penelitian ini menggunakan data perusahaan yang tergolong indeks LQ45 sebagai return pasar. Return pasar diperoleh dengan rumus (Hartono, 2015:408):

$$
R_{m, t}=\frac{I H S G_{t}-I H S G_{t-1}}{I H S G_{t}}
$$

Keterangan:

$R_{m, t} \quad=$ Return indeks pasar pada hari ke $-\mathrm{t}$

$I H S G_{t} \quad=$ Indeks harga saham gabungan penutupan pada hari ke $-\mathrm{t}$

$I H S G_{t-1}=$ Indeks harga saham gabungan penutupan pada hari ke t-1

Setelah menghitung return realisasian dan return ekspektasian maka langkah selanjutnya adalah menghitung abnormal return. Abnormal return adalah selisih antara return sesungguhnya yang terjadi dengan return ekspektasian yang dirumuskan sebagai berikut (Hartono, 2015:647):

$$
\operatorname{RTN}_{\mathrm{i}, \mathrm{t}}=\mathrm{R}_{\mathrm{i}, \mathrm{t}}-\mathrm{E}\left[\mathrm{R}_{\mathrm{i}, \mathrm{t}}\right]
$$

Keterangan:

$\mathrm{RTN}_{\mathrm{i}, \mathrm{t}}=$ return tak normal (abnormal return) sekuritas ke-i pada periode peristiwa ke-t

$\mathrm{R}_{\mathrm{i}, \mathrm{t}} \quad=$ return realisasian yang terjadi untuk sekuritas ke-i pada periode peristiwa ke-t

$\mathrm{E}\left[\mathrm{R}_{\mathrm{i}, \mathrm{t}}\right]=$ return ekspektasian sekuritas ke-i untuk periode peristiwa ke-t

Tahap terakhir adalah menghitung Cumulative Abnormal Return (CAR). Cumulative abnormal return merupakan penjumlahan return tak normal hari sebelumnya di dalam periode peristiwa untuk masing-masing sekuritas, dapat dihitung dengan rumus sebagai berikut (Hartono, 2015:663):

$$
C A R_{i, t}=\sum_{t=t 3}^{t=0} A R_{i, t}
$$




\section{Keterangan :}

$\mathrm{CRTN}_{\mathrm{i}, \mathrm{t}}=$ Cumulative Abnormal Return perusahaan ke i periode t, yang diakumulasi dari $\mathrm{AR}_{\mathrm{it}}$ sekuritas ke-i, periode peristiwa (t-3) sampai dengan $(\mathrm{t}+3)$

Populasi penelitian ini adalah saham-saham perusahaan yang tergolong indeks LQ45 periode Agustus 2018 sampai dengan Januari 2019 yang terdaftar dalam Bursa Efek Indonesia. Alasan menggunakan saham-saham perusahaan yang tergolong indeks LQ45, karena sahamnya memiliki karakteristik dengan tingkat likuiditas tinggi sehingga mudah untuk diperdagangkan dan memiliki kapitalisasi pasar di BEI yang relatif besar. Oleh karena itu saham yang tergolong LQ45 ini memberikan gambaran akurat akan perubahan nilai pasar dari seluruh saham yang aktif diperdagangkan di BEI (Fakhruddin \& Hadianto, 2001:203).

Pengambilan sampel dalam penelitian ini didasarkan atas pertimbangan sebagai berikut: 1) Perusahaan yang tergolong Indeks LQ45 periode Agustus 2018 sampai dengan Januari 2019 di Bursa Efek Indonesia. 2) Tidak melaksanakan corporate action pada periode pengamatan atau jendela peristiwa penelitian yaitu periode 2018 agar terhindar dari confounding effect yang dilakukan oleh aksi korporasi perusahaan. Corporate action yaitu stock split, pengumuman dividen, right issue, saham bonus dan penerbitan warrant. Tahapan analisis data yang dilakukan yaitu Statistik Deskriptif, Uji Normalitas dan Uji One Samples T-Test.

\section{HASIL DAN PEMBAHASAN}

Hasil analisis data ini merupakan hasil pengamatan menggunakan metode studi peristiwa mengenai kesepakatan investasi bidang infrastruktur dalam pertemuan tahunan IMF-World Bank 2018, dimana kesepakatan mengenai investasi ini 
diumumkan pertama kali pada tanggal 8 Oktober 2018. Periode pengamatan menggunakan 7 hari pengamatan, yaitu 3 hari sebelum pengumuman, hari $\mathrm{h}$ pengumuman, dan 3 hari sesudah pengumuman. Penelitian ini dilakukan pada perusahaan yang terdaftar dalam Indeks LQ-45 periode Bulan Agustus 2018 sampai dengan Januari 2019. Pemilihan Indeks LQ-45 (Indeks Liquid-45), karena dibentuk dari 45 saham-saham yang paling aktif diperdagangkan. Selain itu, Indeks LQ-45 juga merupakan indeks saham yang terdiri dari 45 saham di Bursa Efek Indonesia dengan likuiditas yang tinggi dan kapitalisasi pasar yang besar.

Sampel penelitian menggunakan metode purposive sampling dengan kriteria perusahaan yang tidak melakukan corporate actions yaitu pembagian deviden, stock split, right issue, saham bonus, dan penerbitan warrant selama periode pengamatan. Prosedur pemilihan sampel dapat dilihat pada Tabel 4.1, berikut ini.

Tabel 1.

Prosedur Pemilihan Sampel Perusahaan

\begin{tabular}{|c|c|c|}
\hline No & Keterangan & Jumlah Perusahaan \\
\hline 1 & $\begin{array}{l}\text { Perusahaan yang tergolong ke dalam Indeks LQ-45 } \\
\text { periode Bulan Agustus } 2018 \text { sampai dengan Januari } \\
2019\end{array}$ & 45 \\
\hline 2 & $\begin{array}{l}\text { Perusahan dalam Indeks LQ-45 periode Bulan Agustus } \\
2018 \text { sampai dengan Januari } 2019 \text { yang melakukan } \\
\text { corporate action selama periode pengamatan: } \\
\text { - } \quad \text { Pembagian Deviden } \\
\text { - } \quad \text { Stock Split } \\
\text { - } \quad \text { Right Issue } \\
\text { - } \quad \text { Saham Bonus } \\
\text { - } \quad \text { Penerbitan Warrant } \\
\\
\text { Total Sampel Penelitian }\end{array}$ & $\begin{array}{l}(2) \\
(0) \\
(0) \\
(0) \\
(0) \\
43\end{array}$ \\
\hline
\end{tabular}


Penelitian ini menggunakan indikator akumulasi return taknormal (cumulative abnormal return) untuk melihat apakah terjadi reaksi pasar atas pengumuman kesepakatan investasi bidang infrastruktur dalam pertemuan tahunan IMF-World Bank 2018 yang diumumkan pada tanggal 8 Oktober 2018. CAR merupakan akumulasi return taknormal (abnormal return) dari masingmasing perusahaan selama 7 hari periode pengamatan. Perhitungan CAR dilakukan melalui beberapa tahapan yakni menentukan tanggal pengumuman (event date), menghitung actual return, expected return, abnormal return, dan terakhir adalah menjumlahkan abnormal return masing-masing perusahaan selama 7 hari periode pengamatan (event window) untuk memperoleh CAR. Hasil perhitungan tersebut dapat dilihat pada lampiran (2, 3, dan 4).

Berdasarkan hasil perhitungan actual return dari 43 perusahaan sampel, terdapat 301 data actual return (7 hari dikali 43 perusahaan). Hasil perhitungan actual return menunjukkan terdapat perusahaan yang memiliki actual return positif, nol, dan negatif. Actual return yang bernilai negatif tersebut mencerminkan harga saham untuk sekuritas ke-i pada hari ke-t lebih rendah dibandingkan harga saham pada hari t-1. Actual return bernilai nol berarti harga saham sekuritas ke-i antara t dan t-1 bernilai sama. Sedangkan actual return yang bernilai positif menunjukkan bahwa harga saham sekuritas ke-i pada hari ke-t lebih tinggi dari hari t-1. Tabel 4.2 berikut ini menyajikan sebaran nilai actual return berdasarkan perhitungan yang telah dilakukan. 
Tabel 2.

Rekapitulasi Komposisi Perhitungan Actual Return Selama Periode Pengamatan

\begin{tabular}{ccccc}
\hline $\begin{array}{c}\text { Periode } \\
\text { Pengamatan }\end{array}$ & Positif & Nol & Negatif & Total \\
\hline $\mathrm{t}-3$ & 22 & 1 & 20 & 43 \\
$\mathrm{t}-2$ & 18 & 2 & 23 & 43 \\
$\mathrm{t}-1$ & 20 & 0 & 23 & 43 \\
$\mathrm{t}-0$ & 14 & 1 & 28 & 43 \\
$\mathrm{t}+1$ & 13 & 0 & 30 & 43 \\
$\mathrm{t}+2$ & 22 & 1 & 20 & 43 \\
$\mathrm{t}+3$ & 12 & 1 & 30 & 43 \\
Total & $121(40,20 \%)$ & $6(1,99 \%)$ & $174(57,81 \%)$ & 301 \\
\hline
\end{tabular}

Sumber: Data diolah, 2018

Tabel 2 menunjukkan bahwa sebagian besar actual return yang terdapat dalam periode pengamatan adalah actual return yang bernilai negatif, yaitu sebanyak 174 actual return atau sebanyak 57,81\%. Sejumlah 121 actual return (40,20\%) bernilai positif dan 6 actual return (1,99\%) bernilai nol. Setelah memperoleh actual return, perhitungan selanjutnya dilakukan untuk mendapatkan expected return. Model ini mengganggap bahwa expected return yang diperoleh sama dengan hasil return pasar harian yang diperoleh dari perhitungan IHSG pada waktu ke-t. hasil perhitungan expected return yang dapat dilihat pada Tabel 3.

Tabel 3.

Hasil Perhitungan Expected Return Harian Selama Periode Pengamatan

\begin{tabular}{ccc}
\hline Tanggal & Periode Pengamatan & $\mathrm{E}(\mathrm{R} \mathrm{i}, \mathrm{t})=\mathrm{Rmt}$ \\
\hline 3 Oktober 2018 & $\mathrm{t}-3$ & -0.001 \\
4 Oktober 2018 & $\mathrm{t}-2$ & -0.019 \\
5 Oktober 2018 & $\mathrm{t}-1$ & -0.004 \\
8 Oktober 2018 & $\mathrm{t}-0$ & 0.005 \\
9 Oktober 2018 & $\mathrm{t}+1$ & 0.006 \\
10 Oktober 2018 & $\mathrm{t}+2$ & 0.004 \\
11 Oktober 2018 & $\mathrm{t}+3$ & -0.020 \\
\hline
\end{tabular}

Sumber: Data diolah, 2018

Hasil perhitungan expected return pada tabel 3 menunjukkan bahwa selama periode pengamatan, nilai dari expected return berfluktuasi. Pada 3 hari 
sebelum pengumuman masing-masing periode pengamatan memiliki expected return yang negatif. Selanjutnya pada periode $\mathrm{t}-0$ sampai $\mathrm{t}+2$ terdapat expected return yang positif, pada hari terakhir kembali terdapat expeted return yang positif. Setelah diperoleh data mengenai actual return dan expected return, maka langkah selanjutnya adalah menghitung abnormal return setiap perusahaan untuk kemudian diakumulasikan sehingga diperoleh CAR. Berikut ini merupakan hasil statistik deskriptif dari CAR selama periode pengamatan peristiwa yang disajikan dalam Tabel 4.

\section{Tabel 4}

Hasil Uji Statistik Deskriptif

\begin{tabular}{lccccc}
\hline & $\mathrm{N}$ & Minimum & Maximum & Mean & Std. Deviation \\
\hline CAR & 43 & $-0,134$ & 0,064 & $-0,023$ & 0,043
\end{tabular}

Valid N (listwise) 43

Sumber: Data diolah, 2018

Berdasarkan tabel 4.4 dari 43 perusahaan yang diteliti melaui periode pengamatan selama 7 hari, diperoleh nilai minimum CAR sebesar -0,134 yang dimiliki oleh Matahari Department Store Tbk (LPPF). Nilai minimum CAR ini menunjukkan bahwa investor yang memiliki saham LPPF memperoleh abnormal return yang paling kecil dan bernilai negatif. Nilai maksimum CAR sebesar 0,064 dimiliki oleh Barito Pacific Tbk. (BRPT). Nilai maksimum CAR ini menunjukkan bahwa investor yang memiliki saham BRPT memperoleh abnormal return yang paling besar. Nilai rata-rata CAR dari 43 perusahaan yang diteliti adalah sebesar 0,023, dengan standar deviasi sebesar 0,043.

Berdasarkan hasil uji normalitas yang diolah menggunakan teknik one sample Kolmogorov-Smirnov dengan software IBM SPSS Statistics 23 diperoleh output uji normalitas yang ditunjukkan oleh tabel 5 berikut ini. 
Tabel 5.

Hasil Uji Normalitas

\begin{tabular}{lrr}
\hline & & CAR \\
\hline $\mathrm{N}$ & & 43 \\
Normal Parameters & Mean & $-0,02265$ \\
& Std. Deviation & 0,042933 \\
Most Extreme Differences & Absolute & 0,081 \\
& Positive & 0,079 \\
& Negative & $-0,081$ \\
Test Statistic & & 0,081 \\
Asymp. Sig. (2-tailed) & & 0,200 \\
\hline Sumber: Data diolah, 2018 & &
\end{tabular}

Dari tabel 4.2 dapat diketahui nilai dari signifikansi (asymptotic sig) dari CAR atas kesepakatan investasi bidang infrastruktur dalam pertemuan tahunan IMF-World Bank adalah sebesar 0,200>0,05, yang berarti bahwa data berdistribusi normal sehingga analisis data bisa dilanjutkan dengan statistik parametrik yaitu uji one sample t-test.

Tabel 6.

Hasil Uji One Sample T-Test

\begin{tabular}{|c|c|c|c|c|c|c|}
\hline \multicolumn{7}{|c|}{ Test Value $=0$} \\
\hline \multirow[b]{3}{*}{ CAR } & \multirow{3}{*}{$\begin{array}{c}\mathrm{t} \\
-3.460\end{array}$} & \multirow[b]{2}{*}{ df } & \multirow[b]{2}{*}{ Sig. (2-tailed) } & \multirow{2}{*}{$\begin{array}{c}\text { Mean } \\
\text { Difference }\end{array}$} & \multicolumn{2}{|c|}{$\begin{array}{l}\text { 95\% Confidence Interval of the } \\
\text { Difference }\end{array}$} \\
\hline & & & & & Lower & Upper \\
\hline & & 42 & 0,001 & $-0,022651$ & $-0,03586$ & $-0,00944$ \\
\hline
\end{tabular}
Sumber: Data diolah, 2018

Berdasarkan tabel uji one sample t-test diperoeh nilai $\mathrm{t}=-3,460$ dengan nilai probabilitas sebesar $0,001<\alpha(0,05)$, yang berarti bahwa terdapat reaksi pasar yang negatif atas kesepakatan investasi bidang infrastruktur dalam pertemuan tahunan IMF-World Bank 2018 sehingga $\mathrm{H}_{1}$ diterima.

Pengujian kandungan informasi dapat digunakan untuk melihat ada atau tidaknya reaksi pasar modal atas suatu peristiwa. Pasar modal akan bereaksi apabila suatu peristiwa mengandung informasi yang ditunjukkan dengan adanya abnormal return. Studi yang mempelajari mengenai reaksi pasar atas suatu 
peristiwa yang informasinya dipublikasikan sebagai suatu pengumuman disebut event study (Hartono, 2015:410)

Salah satu peristiwa yang dapat dijadikan sebagai informasi eksternal yang diyakini dapat mempengaruhi pergerakan harga saham di pasar modal saat ini adalah adanya Kesepakatan Investasi Bidang Infrastruktur dalam Pertemuan Tahunan International Monetary Fund-World Bank 2018 yang diumumkan pada tanggal 8 Oktober 2018 untuk kemudian ditandatangani pada tanggal 11 Oktober 2018 di Nusa Dua, Bali. IMF dan World Bank merupakan lembaga yang bergerak di bidang perekonomian moneter dunia. IMF dan World Bank memeiliki fungsi yang berbeda. IMF adalah organisasi internasional yang bertujuan untuk mendorong kerjasama internasional dan menjaga stabilitas keuangan, memfasilitasi perdagangan internasional, mendukung pertumbuhan ekonomi serta penyerapan tenaga kerja, dan mengurangi kemisikinan di dunia. Sedangkan World Bank bisa dikatakan sebagai bank-nya negara-negara di dunia yang berfungsi menyediakan pinjaman kepada negara berkembang untuk program pemberian modal, dengan tujuan untuk pengurangan kemiskinan.

Beberapa tokoh besar dunia yang turut meramaikan Pertemuan Tahunan IMF-World Bank 2018. Seperti Direktur Pelaksana IMF Christine Lagarde, Presiden World Bank Jim Young-Kim, dan Gubernur Bank Sentral Amerika Serikat (The Fed) Jarome Hayden Powell. Selain The Fed, Gubernur Bank Sentral Uni Eropa Mario Draghi dan Gubernur dari Bank Sentral Jepang Haruhiko Kuroda turut hadir dalam Pertemuan Tahunan IMF-World Bank 2018. Ada pula beberapa tokoh korporasi besar yang datang, seperti pendiri Alibaba Group Jack 
Ma, pendiri Microsoft Bill Gates dan beberapa tokoh korporasi lain. Disamping itu, juga hadir Presiden Republik Indonesia Joko Widodo, beberapa menteri juga ikut serta seperti Menteri Keuangan Sri Mulyani, Menteri Koordinator Bidang Kemaritiman Luhut Binsar Pandjaitan, dan para petinggi negara lainnya.

Menurut Direktur Pengembangan Bursa Efek Indonesia (BEI) Hasan Fauzi berharap, ajang pertemuan Tahunan IMF-World Bank 2018 dapat meningkatkan minat investasi global di pasar modal dalam negeri. "Harapannya investor asing bisa melihat objektif prospek perekonomian RI yang secara langsung berkaitan dengan prospek emiten di pasar modal. Jadi semoga IMF ini bisa mendorong investor global untuk berinvestasi melalui berbagai macam instrumen yang ada." (https://www.liputan6.com, diakses tanggal 19 Oktober 2018).

Penandatanganan investasi ini diyakini oleh beberapa pengamat akan menciptakan sentimen positif bagi investor karena nilai investasi yang besar tersebut menunjukkan bahwa Indonesia merupakan tempat berinvestasi yang tepat dan aman. Hal ini juga didukung oleh pernyataan beberapa tokoh penting dunia di bidang ekonomi yang memuji fundamental dan pertumbuhan ekonomi Indonesia yang stabil. Menteri BUMN ini berharap para investor mengetahui adanya komitmen pemerintah yang tinggi untuk mendorong peran pihak swasta dalam untuk turut serta dalam pembangunan infrastruktur dan inovasi instrumen keuangan untuk pembiayaan infrastruktur. Oleh karena itu, adanya peranan pasar modal dalam pendanaan proyek infrastruktur ini diyakini akan menarik minat investor di pasar modal. 
Investasi bidang infrastruktur ini tentunya bertujuan untuk mengembangkan infrastruktur di Indonesia yang bermanfaat dalam mendorong pertumbuhan ekonomi antar daerah karena mobilisasi barang dan jasa antar daerah semakin mudah, sehingga akan menciptakan pertumbuhan ekonomi Indonesia yang lebih baik lagi. Penelitian Juita (2013) menemukan pertumbuhan ekonomi berpengaruh signifikan dan arahnya positif terhadap pasar modal Indonesia yang bisa dilihat dari Indeks Harga Saham Gabungan (IHSG). Selain itu, dengan terciptanya pertumbuhan ekonomi tersebut maka akan meningkatkan sentimen positif terhadap pasar modal Indonesia sehingga mampu menarik minat investor khususnya investor asing untuk berinvestasi.

Reaksi pasar atas sebuah peristiwa baik yang berasal dari internal maupun eksternal perusahaan maupun dari informasi ekonomi atau non ekonomi dapat dilihat dari cumulative abnormal return (CAR) yang dimiliki perusahaan selama periode peristiwa yang dihitung berdasarkan metode market-adjusted model. Berdasarkan hasil uji hipotesis yang telah dilakukan dapat diketahui bahwa nilai probabilitas $0,001<\alpha(0,05)$, maka hipotesis 1 diterima. Hal tersebut berarti sesuai dengan grand theory kandungan informasi yang menyatakan bahwa kandungan informasi suatu pengumuman dapat dilihat dari ada atau tidaknya reaksi pasar modal.

Jadi berdasarkan teori tersebut maka terdapat kandungan informasi yang ditunjukkan dengan adanya reaksi pasar atas pengumuman kesepakatan investasi bidang infrastruktur dalam pertemuan tahunan IMF-World Bank 2018. Namun nilai negatif dari thitung yaitu sebesar -3.460 , menunjukkan bahwa pasar bereaksi 
negatif terhadap pelaksanaan perteman tahunan IMF-World Bank 2018 ini khususnya saat adanya pengumuman mengenai kesepakatan investasi dalam bidang infrastruktur. Hal ini tentunya tidak sesuai dengan pandangan dan prediksi para pakar terkait dampak positif kesepakatan investasi bidang infrastruktur dalam pertemuan tahunan IMF-World Bank 2018 terhadap pasar modal di Indonesia. Hal tersebut bisa disebabkan oleh informasi mengenai kesepakatan investasi ini tidak sampai ke telinga investor dikarenakan investor cenderung lebih bereaksi terhadap adanya perang dagang antara Cina dan Amerika Serikat beberapa bulan belakangan ini yang memberikan dampak negatif terhadap perdangan saham di BEI.

Investasi yang disepakai dalam pertemuan tahunan IMF-World Bank ini merupakan investasi dalam bidang infrastruktur yang dampaknya akan dirasakan dalam jangka panjang sehingga para investor kemungkinan masih menunggu bagaimana realisasi dari investasi ini. Jadi meskipun beberapa pakar dan tokoh di bidang ekonomi meyakini bahwa pelaksanaan IMF-World Bank ini dapat memberikan sentimen positif terhadap pasar modal Indonesia, hal tersebut masih belum bisa melepaskan pasar modal Indonesia dari pengaruh perang dagang Amerika Serikat (AS) dan Cina yang dampak negatifnya dirasakan oleh perekenomian dunia sehingga dapat dikatakan bahwa adanya abnormal return yang negatif lebih disebabkan oleh faktor ekonomi secara makro.

Perang dagang antara dua raksasa ekonomi dunia yaitu AS dan Cina yang diikuti dengan peningkatan suku bunga dari bank sentral Amerika The Fed (Federal Reserve System) sehingga para investor asing memilih untuk menarik 
dananya dari Indonesia khususnya dari pasar modal Indonesia untuk kemudian disimpan dalam bentuk investasi dan tabungan (Wicaksono \& Yasa, 2017). Fed Rate adalah tingkat suku bunga yang digunakan sebagai tolok ukur bagi suku bunga pinjaman maupun simpanan bagi bank atau lembaga-lembaga keuangan oleh The Fed (Wicaksono \& Yasa, 2017). Aktivitas The Fed akan mempengaruhi ekonomi internasional seperti halnya transaksi valuta asing oleh Federal Reserve akan berpengaruh terhadap nilai tukar dolar dan pada akhirnya (Nellawati \& Isbanah, 2019)

Kebijakan peningkatan suku bunga The Fed ini juga menyebabkan melemahnya nilai rupiah terhadap dolar AS karena jumlah dolar yang beredar menjadi berkurang, hal ini didukung oleh beberapa penelitian sebelumnya yakni penelitian (Gom, 2013), (Misgiyanti \& Zuhroh, 2009), dan (Surbakti \& Tjun, 2011). (Dewi, 2016) menyatakan bahwa pelemahan nilai tukar rupiah terhadap dolar AS tersebut dapat mencerminkan bahwa perekonomian Indonesia tidak terlalu baik sehingga menimbulkan sentimen negatif di kalangan investor terhadap pasar modal Indonesia sehingga IHSG juga ikut melemah. Fluktuasi nilai tukar rupiah terhadap mata uang asing akan sangat mempengaruhi iklim investasi di dalam negeri khususnya di pasar modal, perusahaan-perusahaan di Indonesia yang sudah go public dengan masih mengandalkan bahan baku impor dari luar negeri akan menerima dampak negatif apabila mata uang rupiah terdepresiasi atau mengalami pelemahan terhadap mata uang dolar AS (Nurwani, 2016). Pelemahan rupiah terhadap dolar AS ini dapat menyeabkan naiknya harga bahan baku sehingga meningkatkan biaya produksi dan selanjutnya akan berimbas pada 
investor untuk melakukan aksi jual terhadap saham-saham yang dimilikinya. Jika hal tersebut dilakukan oleh banyak investor maka akan berdampak pada pelemahan IHSG.

Berdasarkan pembahasan hasil penelitian, implikasi teoritis dari hasil penelitian ini adalah pengumuman kesepakatan investasi bidang infrastruktur dalam pertemuan tahunan IMF-World Bank direaksi negatif oleh pasar. Hasil penelitian ini sesuai dengan teori kandungan informasi bahwa kandungan informasi suatu peristiwa dapat dicerminkan dari adanya rekasi pasar pada pasar modal, meskipun reaksi yang ditimbulkan adalah reaksi negatif. Selain itu penelitian ini juga diharapkan bisa menjadi tambahan refrensi bagi penelitipeneliti selanjutnya mengenai reaksi pasar atas peristiwa non ekonomi.

Implikasi praktis dari penelitian ini adalah hasil penelitian ini dapat dijadikan pertimbangan bagi investor untuk berinvestasi terkait adanya kesepakatan-kesepakatan yang dilakukan oleh pemerintah. Disamping itu, hasil penelitian ini juga bermanfaat bagi investor untuk memperhatikan faktor-faktor lainnya seperti faktor makro ekonomi sebelum mengambil keputusan berinvestasi yang didasarkan pada pendapat-pendapat pakar maupun tokoh tertentu yang mengarah pada sentimen positif terhadap pasar modal dalam hal ini adalah kesepakatan investasi bidang infrastruktur dalam IMF-World Bank 2018 senilai 200 Triliun.

\section{SIMPULAN}

Simpulan yang diperoleh yaitu selama tujuh hari perdagangan saham di sekitar pengumuman kesepakatan investasi bidang infrastruktur dalam pertemuan 
tahunan IMF-World Bank 2018 dengan menggunakan variabel cumulative abnormal return (CAR) pada perusahaan yang terdaftar indeks LQ 45 serta tanpa melibatkan confounding effect (pengumuman lain) menunjukkan bahwa terdapat reaksi pasar atas pengumuman tersebut. Hasil uji one sample t-test menghasilkan bahwa terdapat reaksi pasar atas pengumuman kesepakatan investasi bidang infrastruktur dalam pertemuan tahunan IMF-World Bank 2018. Hal tersebut menunjukkan bahwa kesepakatan tersebut memiliki kandungan informasi yang cukup bagi investor dalam mengambil keputusan investasi terhadap perusahaanperusahaan yang terdaftar dalam indeks LQ 45. Namun di sisi lain reaksi negatif yang ditunjukkan oleh uji one sample t-test, mencerminkan bahwa pasar modal Indonesia masih belum lepas dari pengaruh perang dagang Amerika Serikat (AS) dan Cina yang dampak negatifnya dirasakan oleh perekenomian dunia.

\section{REFERENSI}

Agustina, L., Gunawan, Y., \& Chandra, W. (2018). The Impact of Tax Amnesty Announcement towards Share Performance and Market Reaction in Indonesia. Accounting and Finance Research, 7(2), 39. https://doi.org/10.5430/afr.v7n2p39

Ahmed, F. Z., \& Alfaro, L. (2017). Market reactions to sovereign litigation. Capital Markets Law Journal, 12(2), 141-163. https://doi.org/10.1093/cmlj/kmx017

Arioglu, E. (2015). Market Reaction to Director Busyness and Expertise. SSRN. https://doi.org/10.2139/ssrn.2595998

Aryasa, I. P. G. C. A. (2017). Reaksi Pasar Sebelum dan Sesudah Pengumuman Right Issue. E-Jurnal Akuntansi Universitas Udayana, 18(2), 1426-1454. https://doi.org/10.1002/gps.1143

Boumosleh, A. S., \& Raad, E. (2011). Market Reaction to Capital Expenditures of Powerful CEOs. SSRN. https://doi.org/10.2139/ssrn.1929389 
Bruno, B., Onali, E., \& Schaeck, K. (2018). Market Reaction to Bank Liquidity Regulation. Journal of Financial and Quantitative Analysis, 53(2), 899-935. https://doi.org/10.1017/S0022109017001089

Dewi, N. N. A. P. (2016). Analisis Pengaruh Pelemahan Nilai Tukar Rupiah Terhadap Harga Saham Sektoral Pada Indeks LQ 45 di Bursa Efek Indonesia. Jurnal Akuntansi Universitas Sanata Dharma. 7(1), 21-35.

Doktorgrades, E. (2016). Capital Market Effects of Taxes and Corporate Tax Avoidance Inauguraldissertation zur Universität zu Köln aus Köln.

Edirisinghe, U. C., \& Nimal, P. D. (2015). Stock Price Reaction to Announcements of Right Issues and Debenture Issues: Evidence from Colombo Stock Exchange. International Journal of Business and Social Research, 5(2), 67-76. https://doi.org/10.18533/IJBSR.V5I2.717

Fakhruddin, M., \& Hadianto, M. (2001). Perangkat dan Model Analisis Investasi di Pasar Modal. Jakarta: Gramedia.

Fama, E. F. (1997). Market Efficiency, Long-Term Returns, and Behavioral Finance. Journal of Financial Economics, 49, 283-306. https://doi.org/10.2139/ssrn.15108

Foster. (1986). Financial Statement Analysis. Englewood, New Jersey: Prentice Hall.

Gom, H. G. O. M. P. (2013). Analisis Pengaruh The Fed Rate, Indeks Dow Jones dan Indeks Nikkei225 Terhadap Indeks Harga Saham Gabungan (IHSG) di Bursa Efek Indonesia ( BEI ) Periode 2008-2013. Jurnal Ekonomi Dan Keuangan, 1(8), 26-38.

Hartono, Jogiyanto. (2015). Teori Portofolio dan Analisis Investasi. Edisi Kesepuluh. Yogyakarta: BPFE.

Huesecken, B., Overesch, M., \& Tassius, A. (2016). Effects of Disclosing Tax Avoidance: Capital Market Reaction to LuxLeaks. SSRN. https://doi.org/10.2139/ssrn.2848757

Husnan, S. (2001). Dasar-dasar Teori Portofolio dan Analisis Sekuritas. Yogyakarta: UPP AMP YKPN.

Jatmiko, D. P., Manahov, V., \& Obiosa, N. (2014). Does capital market reaction to non-Economic factors generate abnormal returns? Investment Management and Financial Innovations, 11(4), 66-76.

Knauer, T., \& Wöhrmann, A. (2016). Market Reaction to Goodwill Impairments. 
European Accounting Review, 25(3), 421-449. https://doi.org/10.1080/09638180.2015.1042888

Liu, J., Akbar, S., Shah, S. Z. A., Zhang, D., \& Pang, D. (2016). Market Reaction to Seasoned Offerings in China. Journal of Business Finance and Accounting, 43(5-6), 597-653. https://doi.org/10.1111/jbfa.12198

Misgiyanti, \& Zuhroh, I. (2009). Pengaruh Suku Bunga Luar Negeri Federal Reserve (The FED ), Nilai Tukar Rupiah/ US \$ dan Inflasi terhadap Indeks Harga Saham Gabungan di Bursa Efek Indonesia Periode 2006-2008. Jurnal Ekonomi Pembangunan, 7, 19-32.

Nanda, R. D. (2017). Reaksi Pasar Modal Indonesia Terhadap Kebijakan Tax Amnesty Indonesia pada Saham LQ45 Tahun 2016 -2017. Business Administration, 1-13.

Nellawati, S. O., \& Isbanah, Y. (2019). Analisis Pengaruh Faktor Internal dan Faktor Eksternal Terhadap Pergerakan Indeks Harga Saham Gabungan (IHSG) di Bursa Efek Indonesia Periode 2012 - 2016, Jurnal Ilmu Manajemen Universitas Negeri Surabaya, 7 (1), 113-123.

Nurwani. (2016). Analisis Pengaruh Harga Minyak Dunia, Inflasi, Dan Suku Bunga Indonesia Terhadap Pergerakan Indeks Harga Saham Gabungan Di Bursa Efek Indonesia.

Pereira, M. A., Securato, J. R., \& Sousa, A. F. de. (2016). Effect of investments on fundamentals and market reaction on pre-operational and operational Brazilian companies for the period 2006-2012. Revista de Administração, 51(1), 056-071. https://doi.org/10.5700/rausp1223

Prameswari, I. A. N. (2017). E-Jurnal Akuntansi Universitas Udayana Analisis Reaksi Pasar Modal Pada Peristiwa Pemilihan Gubernur DKI Jakarta Tahun 2017. E-Jurnal Akuntansi Universitas Udayana. 22(2), 944-975. http:/doi.org/10.24843/EJA.2018.v22.i02.p05

Pratama, I. G. S., \& Sudhiarta, G. M. (2014). Analisis Perbandingan Abnormal Return Saham Sebelum dan Sesudah Pengumuman Right Issue. E-Jurnal Manajemen Universitas Udayana, 3(1), 243-257.

Purba, F., \& Handayani, S. R. (2017). Analisis Perbedaan Reaksi Pasar Modal Indonesia Sebelum dan Sesudah Peristiwa Non Ekonomi. Jurnal Administrasi Bisnis (JAB), 51(1), 115-123.

Putra, I. M. D. H. (2018). Analisis Reaksi Pasar Sebelum dan Sesudah Pengumuman Kemenangan Donald Trump Menjadi Presiden Amerika Serikat, E-Jurnal Akuntansi Universitas Udayana, 23(1). April (2018): 406- 
435. https://doi.org/10.24843/EJA.2018.v23.i01.p16

Quaye, I., Mu, Y., Abudu, B., \& Agyare, R. (2016). Review of Stock Markets' Reaction to New Events: Evidence from Brexit. Journal of Financial Risk Management, 05(04), 281-314. https://doi.org/10.4236/jfrm.2016.54025

Sari, N. P. T., \& Permata. (2017). Analisis Komparatif Saham LQ45 Sebelum dan Sesudah Pilpres Amerika Serikat 2016. E-Jurnal S1 Akuntansi Universitas Pendidikan Ganesha, 7 (1), 1-10.

Setiawan, D., Phua, L. K., \& Chee, H. K. (2017). CEO turnover and market reaction in Indonesia. Indonesia Capital Market Review, 5(2), 85-94.

Sopyana, N. P. (2016). Pemilihan Presiden dan Wakil Presiden Republik Indonesia Tahun 2014, Jurnal Buletin Studi Ekonomi, 21(2), 136-146.

Sudewa P, D. G. O., \& Maria M, R. S. (2015). Reaksi Pasar Atas Peristiwa Pilpres 2014. E-Jurnal Akuntansi Universitas Udayana, 12 (3), hal.465-480.

Suparsa, I. M. J., \& Ratnadi, N. M. D. (2014). Perbedaan Abnormal Return dan Trading Volume Activity atas Pengumuman Kenaikan Harga BBM Pada Saham yang Tergolong LQ 45. E-Jurnal Akuntansi Universitas Udayana, $7(2), 382-389$.

Surbakti, E. P. A., \& Tjun, L. T. (2011). Pengaruh Non Farm Payroll , Suku Bunga Bank Sentral Amerika Serikat ( The Fed ), dan Indeks Nikkei 225 Terhadap Indeks dari Saham-saham Perusahaan Berbasis Syariah di Jakarta Islamic Index. Jurnal Akuntansi, 3(1), 34-52.

Tandelilin, E. (2010). Portofolio dan Investasi. Edisi Pertama. Yogyakarta: Kanisius.

Watts, R. L., \& Zimmerman, J. L. (1986). Positive Accounting Theory, Englewood, New Jersey: Prentice Hall.

Wicaksono, I. S., \& Yasa, G. W. (2017). Pengaruh Fed Rate, Indeks Dow Jones, Nikkei 225,Hang Seng Terhadap Indeks Harga Saham Gabungan. Jurnal Akuntansi Universitas Undayana, 18(1), 358-385. https://doi.org/2302-8556

Widi, P., \& Surya, A. (2015). Analisis Perubahan Volume Perdagangan Saham dan Abnormal Return Sebelum dan Sesudah Pemilu Legislatif 9 April 2014: Event Study Pada Sektor Industri di Bursa Efek Indonesia. E-Jurnal Akuntansi Universitas Pendidikan Ganesha, 3 (1), 1-11.

Xiao, X., \& Gao, Y. (2017). An Event Study of The Effects of Regulatory Changes on The Food Industry. China Agricultural Economic Review, 9(1), 
P. Sigit Wahyudi dan I G. N. Agung Suaryana. Reaksi ...

81-92. https://doi.org/10.1108/CAER-01-2014-0006

Yang, H. I. (2012). Capital market consequences of managers' voluntary disclosure styles. Journal of Accounting and Economics, 53(1-2), 167-184. https://doi.org/10.1016/j.jacceco.2011.08.003 